\title{
Analysis and evaluation of stability for the reactivated landslide along deep-seated weakness zones
}

\author{
Boo-Seong Park', Hyun Cho, Sung-Pill Youn and Dong-In Park
}

${ }^{*}$ Correspondence: bspark@ssyenc.com

Ssangyong Engineering and Construction Co., Ltd., Seoul 05510, Korea

\begin{abstract}
In areas where landslides have occurred in the past, it is prone to additional landslides because of similar geological and geographical characteristics. A slope sliding by a reactivated landslide can result in accidents, extra cost and delayed construction schedule. Hence, it is important to identify evidence of past landslides during the design and construction phases in these areas. In the study area presented in this paper, tension cracks were found during clearing and grubbing work prior to the construction of cut slopes at a tunnel portal, implying that landslides had occurred in the past. To mitigate risk, slope gradient was decreased to 1:1.3 with removal of tension cracks, however, $90 \mathrm{~m}$-long tension cracks occurred subsequently. Therefore, detailed geotechnical investigations and analysis were carried out. This paper aims to present procedures and results of analysis to clarify causes of landslides, including selection of the optimum countermeasures for stabilization of the cut slope. We hope that this case study will provide useful information to other engineers and contribute to the prevention of disaster caused by landslide.
\end{abstract}

Keywords: Reactivated landslide, Tension cracks, Anorthosite, Weakness zones, Clayey layers, Hydrothermal alteration, Countermeasures

\section{Background}

Severe damage in construction sites have been reported due to slope sliding. And it is becoming more frequent as infrastructure projects such as roads and railways in mountainous and hilly areas increase for effective land resources utilization. Landslides can cause great damage to properties, injuries and even death in severe cases because of relatively large-scale failures. The main causes of landslides are linked to geological characteristics, gravity, weather, groundwater, wave action and human actions [1]. Therefore, the areas where landslides occurred in the past and their surroundings have high probabilities of subsequent slope failures during construction due to reactivated landslides because they have similar geological and geographical conditions. Hence, it is important to identify evidence of past landslides in these areas during the design and construction phases in order to minimize project risks such as accidents, increased cost and delayed schedule. To identify evidence of landslides in the past, detailed investigations of natural slopes should be conducted to uncover the histories, to clarify critical factors that might

(C) 2016 Park et al. This article is distributed under the terms of the Creative Commons Attribution 4.0 International License (http:// creativecommons.org/licenses/by/4.0/, which permits unrestricted use, distribution, and reproduction in any medium, provided you give appropriate credit to the original author(s) and the source, provide a link to the Creative Commons license, and indicate if changes were made. 
cause slope failures and to establish countermeasures against expanding or subsequent landslides.

In the study area presented in this paper, it was difficult to observe any signs of landslides, for instance, tension cracks, during the design and preparation of construction phases due to dense bushes and trees on the surface of the natural slope. However, evidence of ground deformation such as tension cracks and scarps caused by historical landslides were observed during clearing and grubbing work. Subsequently, another large-scale tension cracks of $90 \mathrm{~m}$ in length were observed across the slope during reduction of slope gradient (1:1.3) to remove the existing tension cracks. As a result, detailed geotechnical investigations such as surface geological survey, electric resistivity survey, boring survey, borehole image processing system (hereinafter referred to as 'BIPS'), seismic tomography, in-situ and laboratory tests were performed.

In this paper, geological features of the study area, status of the landslides, results of investigations and analysis to clarify causes of the landslides are presented, including proposed countermeasures against potential slope failures.

\section{Overview of geological features}

The study area is located in Bukcheon-myeon, Hadong-gun, Gyeongsangnam-do, Korea. According to the regional geological data [2], the bedrock of the study area mainly consists of age-unknown gneisses and igneous rocks (anorthosite, diorite), Jurassic sedimentary rocks and Cretaceous igneous rocks (syenite, granodiorite, quartz porphyry, dykes). And alluvial deposits of Quaternary Period are unconformably overlaying them. According to the detailed geological data, the study area including the slope at the tunnel portal is composed of sedimentary rock formation, named Wonji Formation, and anorthosite. The upper part of the slope consists of sedimentary rocks such as conglomerate, sandstone and shale. The lower part of the slope consists of an altered and weathered zone in anorthosite. Especially, there exists a geologic boundary, forming an unconformity between conglomerate and anorthosite. Joints and a fracture zone in conglomerate and clayey layers by alteration and weathering in anorthosite are assumed to be caused by high stress due to an intrusion of quartz porphyry. The geological map of the study area and the schematic diagram of the stratification are shown in Figs. 1 and 2.

\section{Status of the landslides}

The cut slope in the study area is located adjacent to the portal of the Cut \& Cover and NATM (New Austrian Tunneling Method) tunnel. It is a large-scale rock slope containing colluvial and weathered soils in the upper part. The dimension of the slope is $85 \mathrm{~m}$ in length and $41 \mathrm{~m}$ in height. In the original design, reduction of slope gradient to 1:0.7 - 1.0 with reinforcement by soil nailing were applied.

In October 2009, while clearing and grubbing work prior to the construction of the slope at the tunnel portal, tension cracks of $40 \mathrm{~m}$ in length and $3-4 \mathrm{~m}$ in depth were discovered in the upper part of the slope. And several tension cracks caused by movement of rock blocks were found in the lower right-hand side of the slope. Also, protruding rocks, vertical offset and scarps in the natural slope were observed. In spite of additional reduction of slope gradient (1:1.3) to stabilize the slope and to remove the existing tension cracks, subsequent large-scale tension cracks (Width: $0.1-0.5 \mathrm{~m}$, Depth: $2-7 \mathrm{~m}$ ) 


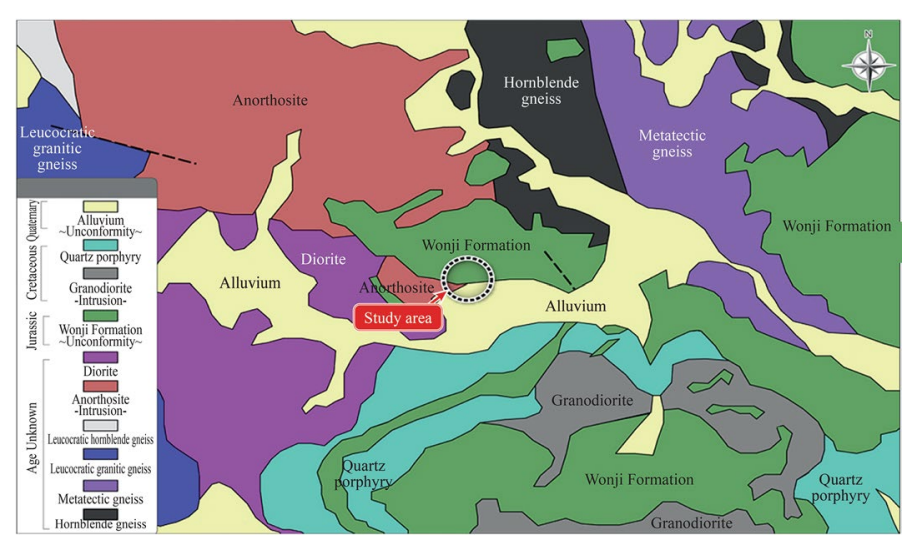

Fig. 1 Geological map of the study area [2]

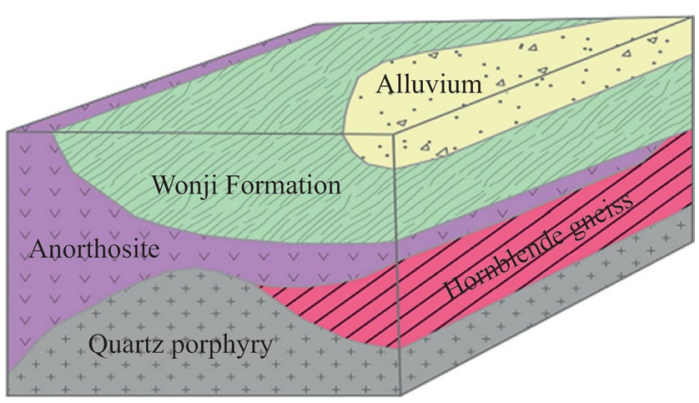

Fig. 2 Schematic diagram of the stratification

which stretches about $80 \mathrm{~m}$ in length across the slope surface occurred in October 2010. Based on this circumstance, it was estimated that the actual depth of the crack would be much deeper and closer to the lower part of the slope. In addition to the large-scale tension cracks, several other tension cracks (Width: $0.1-0.4 \mathrm{~m}$, Depth: $1-3 \mathrm{~m}$ ) occurred, intersecting the existing tension cracks. Following this, the ground deformation including the additional tension cracks (approximately $10 \mathrm{~m}$ in length) and the vertical offset by the extension of main tension cracks (Length: $80 \mathrm{~m}$ ) were discovered. The status of the slope before and during the excavation are presented in Figs. 3 and 4. The analysis map of the landslides is shown in Fig. 5.

\section{Analysis on causes of landslides through geotechnical investigations}

\section{Geotechnical investigations for cause analysis}

The detailed geotechnical investigations such as surface geological survey, electric resistivity survey, boring survey, BIPS, seismic tomography, in-situ and laboratory tests were performed three times in order to gather information on features of strata, lithology, geological structures and engineering properties of rocks. Various types of geotechnical investigations for the study area and its surrounding were conducted including three times of surface geological surveys, 24 survey lines of electric resistivity survey, 21 holes of boring survey, three times of BIPS, a seismic tomography, etc. The results of 


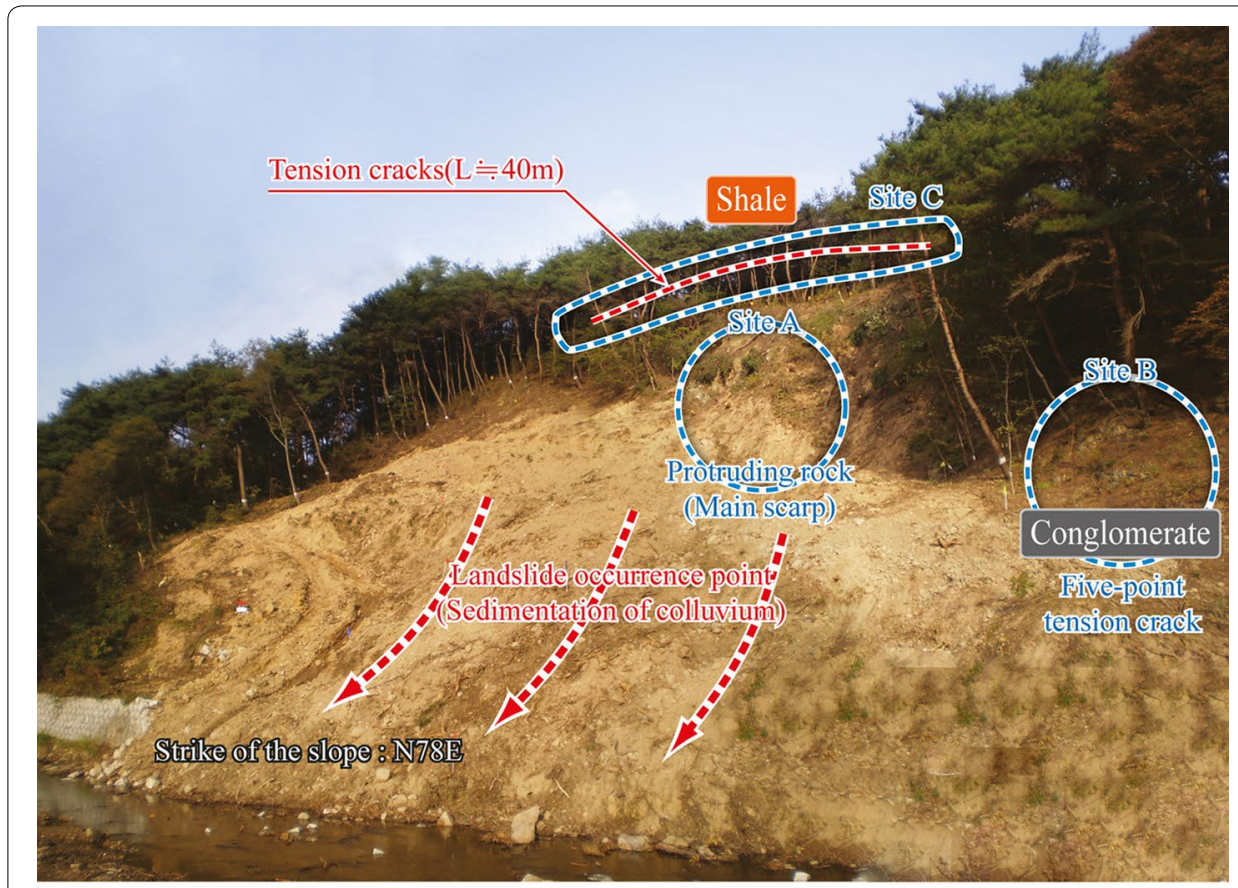

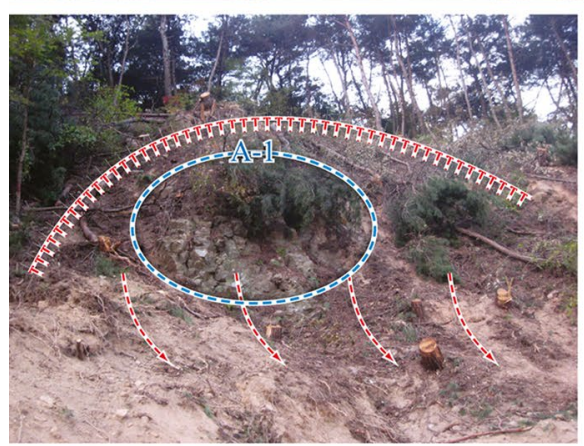

a Site $\mathrm{A}$

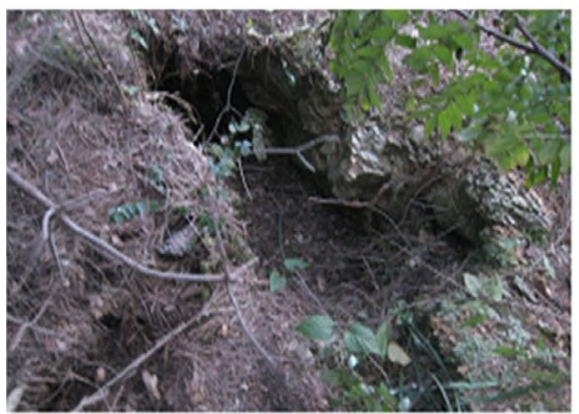

c Site C

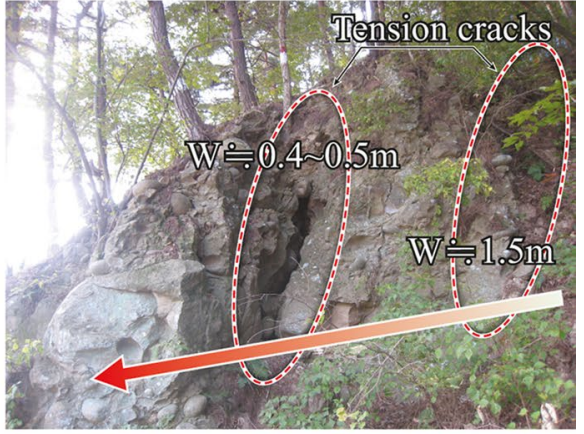

b Site B

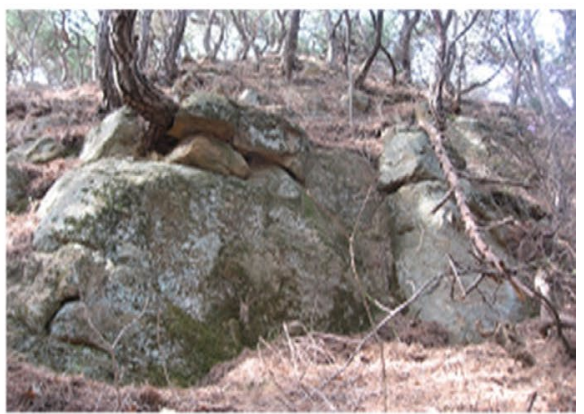

d Main scarp of the rear slope

Fig. 3 Status of the slope before excavation

geotechnical investigations [3] were used for analysis on causes of the landslides and the selection of countermeasures. The locations and the types of the geotechnical investigations applied for the study area are presented in Fig. 6. And the results of the geotechnical investigations are described in the following sections. 

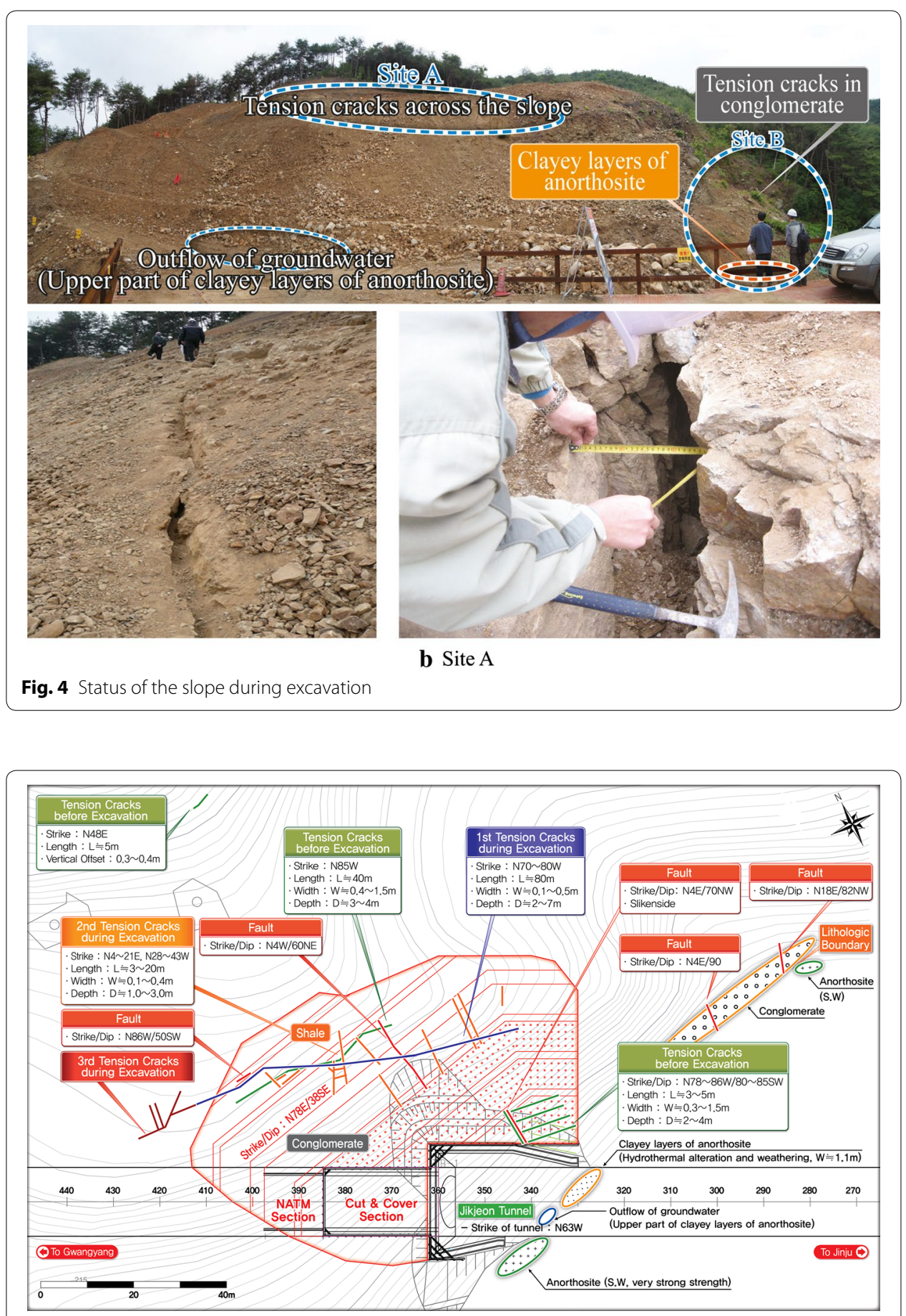

Fig. 5 Analysis map of the landslides

\section{Surface geological survey}

The study area is composed of sedimentary rocks, named Wonji Formation, and anorthosite. There were various types of discontinuities such as joints, bedding planes and fault zones in the sedimentary rocks. These discontinuities allowed inflow of groundwater which resulted in rapid weathering of the rocks. And weathering and 


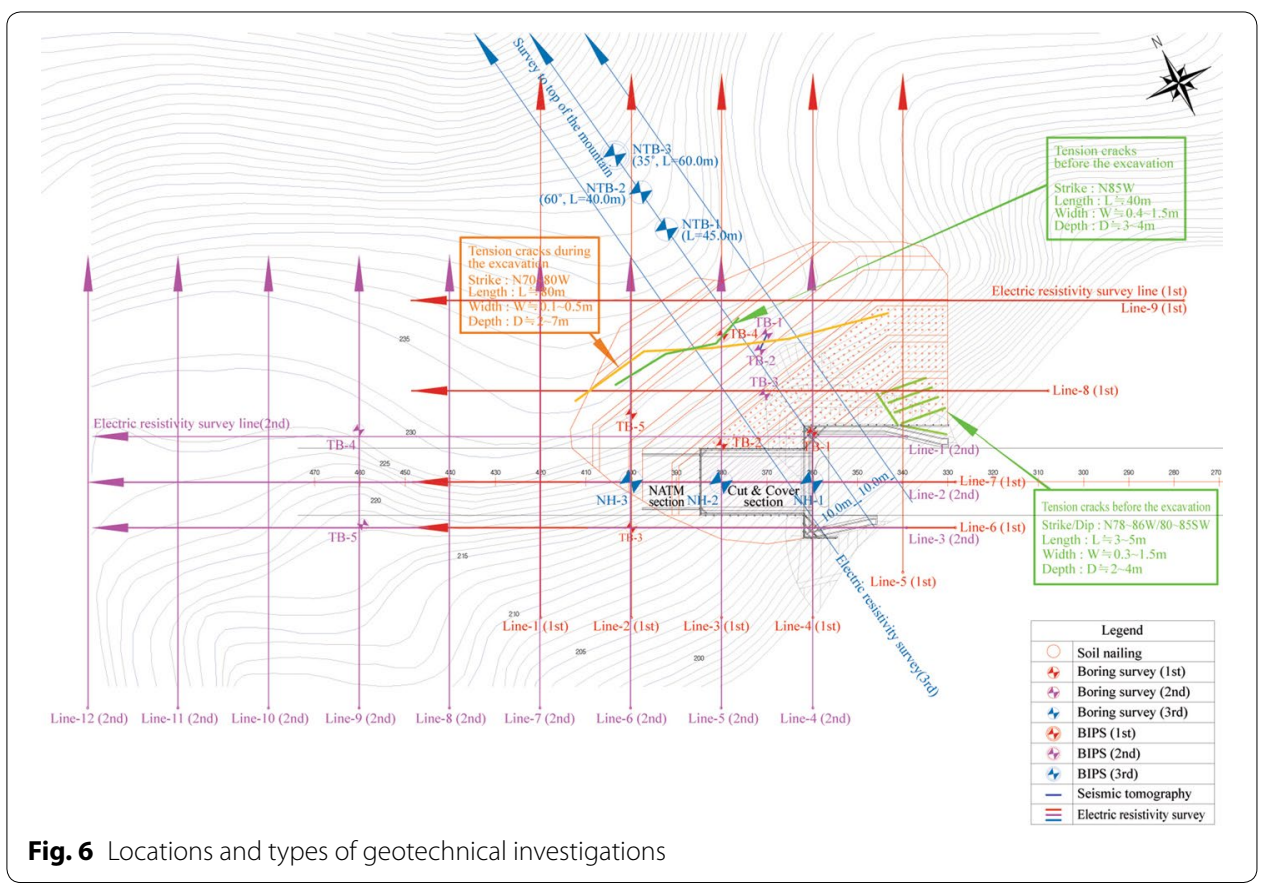

hydrothermal alteration transformed the upper part of anorthosite into a clay-like soil. The weathered zone of anorthosite exists in the lower right-hand side of the slope. The fault zone and the lithologic boundary between basal conglomerate and anorthosite were observed in the study area. Changes in geological and geographical environment including groundwater inflow into the unconformity might decrease shear strength along the lithologic boundary. This, in turn, can be assumed to induce the tension cracks in the upper sedimentary rocks. The engineering geological map of the slope is presented in Fig. 7.

\section{Electric resistivity survey}

An Electric resistivity survey was carried out to examine the distribution of weakness zones. The survey was performed on 24 survey lines with grid pattern. As shown in

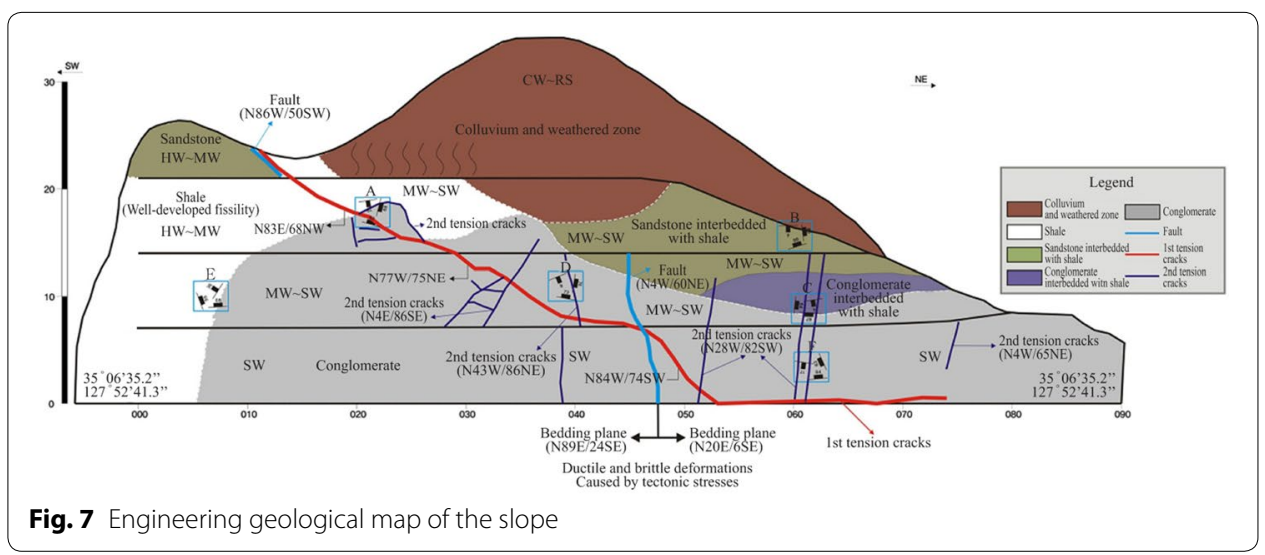




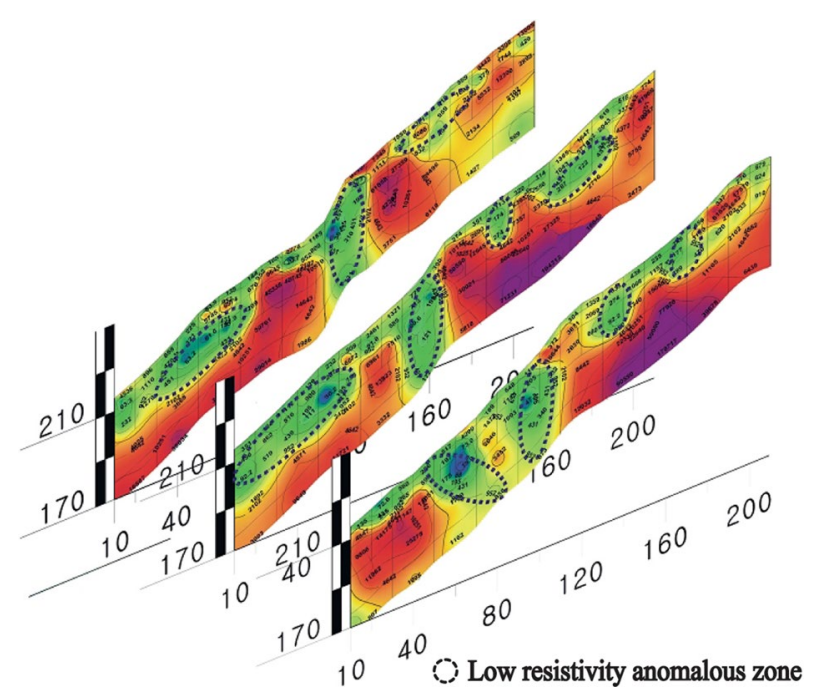

Fig. 8 Results of the electric resistivity survey

Fig. 8, the low resistivity zone below $500 \Omega \mathrm{m}$ is located from G.L(-) $20 \mathrm{~m}$ to G.L(-) $30 \mathrm{~m}$, showing the horizontal continuity which could be a result of the existing fracture zone and the lithologic boundary. Also, the vertical low resistivity zone influenced by tectonic process is located $130 \mathrm{~m}$ apart from the center line of the tunnel with a depth deeper than $40 \mathrm{~m}$.

\section{Boring survey}

The strata of this study area consist of colluvial soil, weathered soil, weathered rock, soft rock and hard rock in order from top to bottom. Colluvium with the thickness of approximately $12 \mathrm{~m}$ is composed of sand, gravel and boulder. Relative densities of these layers are considered as loose with the SPT (Standard Penetration Test)-N values ranging between 4 and 7. It can be inferred that the study area has historical records of landslides on the grounds of thickly deposited colluvium. The sedimentary rocks primarily consist of conglomerate and shale filled with clayey materials with many discontinuities driven by joints, bedding planes and faults. Discoloration of joint surfaces as a result of continuous weathering process was observed.

During the boring survey, there were several sections where rock cores had not collected. It indicates that there exists fracture or weathered zones formed by highly weathering or tectonic process. Anorthosite is distributed in the lower part of the sedimentary strata. There is a partially fractured zone near the lithologic boundary between the sedimentary rocks and anorthosite. And a number of clayey layers and hydrothermal alteration zones interbedded each other are spread around the boundary. The clayey layers formed by alteration and weathering with the average thickness of $1-2 \mathrm{~m}$ exists, slanting $10-15^{\circ}$ upward. Anorthosite which showed a good rock quality was distributed in the lower part of the weakness zone. It is found that the fracture zone, the clayey layers and the hydrothermal alteration zone of anorthosite might adversely affect the slope stability. Boring cores showing the lithologic boundary are presented in Fig. 9. 


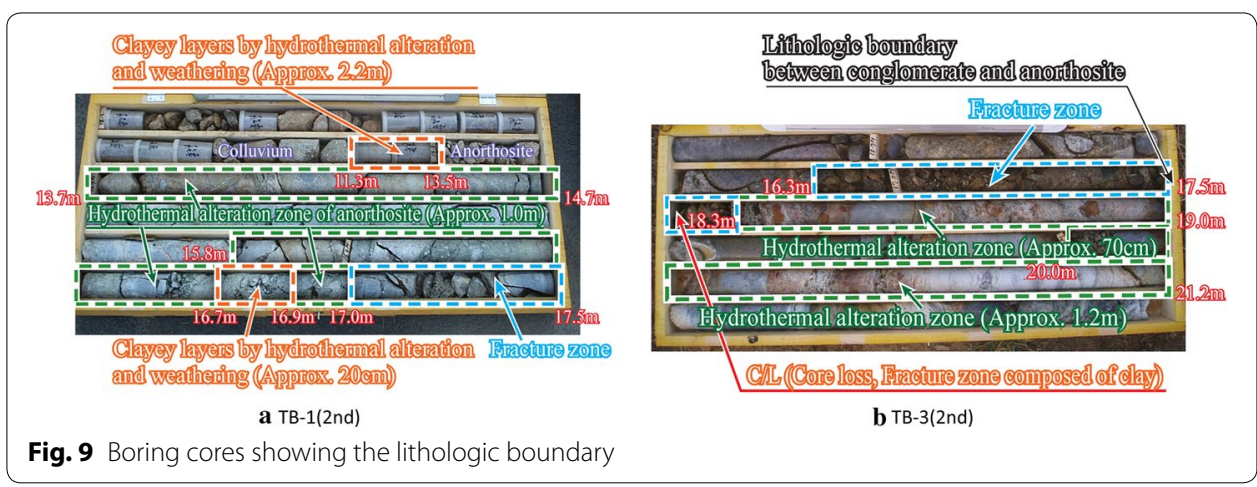

\section{BIPS (Borehole image processing system)}

The BIPS was applied to the TB-2(1st), TB-4(1st), TB-1(2nd), TB-2(2nd) and NTB$3(3 \mathrm{rd})$ to determine types of rocks and dominant trends of discontinuities. As a result of the BIPS, it is found that the slope primarily consists of highly weathered and fractured rocks. The dominant dip varies from 10 to 70 degrees, and the dominant space ranges from 60 to $600 \mathrm{~mm}$. In the case of TB-2(2nd), the dominant dip is mainly presented around $30-40^{\circ}$, and the joint space appears mainly in a range of $200-600 \mathrm{~mm}$. During boring for the BIPS, boreholes are collapsed and washed away in the fracture zone developed around the lithologic boundary between conglomerate and anorthosite. Fig. 10 represents results of the BIPS (TB-2(2nd)) showing the fracture zone and the lithologic boundary.

\section{Analysis on causes of landslide}

Analysis of tension cracks

Weakness zones such as the fracture zone, the clayey layers and the hydrothermal alteration zone of anorthosite are distributed in the ground. Tension cracks and scarps were found in the upper part of the slope. The clayey layers of anorthosite was exposed in the lower part of it, showing the horizontal continuity. According to the result of the boring survey, the fracture zone and the clayey layers caused by hydrothermal alteration and weathering were found around the lithologic boundary between the sedimentary rocks and anorthosite. Using the electric resistivity survey, it was discovered that the low resistivity zone is related to the tectonic zone and the characteristics of the strata. Through comparison with the results of the boring survey, it was verified that the weakness zone has high correlation to the low resistivity zone below $500 \Omega \mathrm{m}$. Taking into consideration of the above-mentioned, it is inferred that the ground deformation occurred during the excavation as a result of reactivated landslides along the lithologic boundary.

\section{Analysis of slip surface}

The inferred slip surface is the weak clayey layers which are developed along the lithologic boundary in the lower part of the slope. The clayey layers were formed due to hydrothermal alteration and inflow of groundwater through the fracture zone, the joints and the bedding plane. A number of tension cracks and scarps were occurred in the upper part of the slope prior to the excavation. The distribution of scarps are similar to 


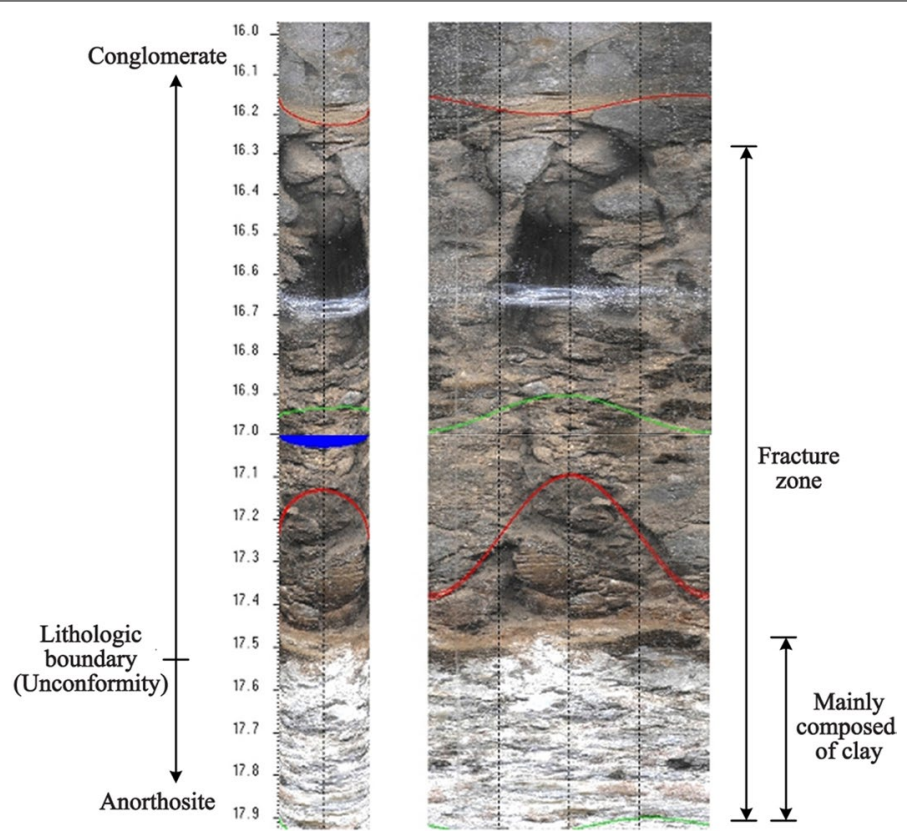

Fig. 10 Example showing the fracture zone and the lithologic boundary by BIPS (TB-2(2nd))

that of the low resistivity zone located $130 \mathrm{~m}$ away from the base point of the measurement. The clayey layers caused by alteration and weathering of anorthosite are assumed to be located in the deep-seated failure surface of the tension cracks. It is inferred that the tension cracks by landslides continuously occurred prior to and during the excavation because of increased water pressure, and deterioration of shear strength and frictional resistance along the clayey layers of anorthosite. The analysis results on the tension cracks and the inferred slip surface of the slope are shown in Fig. 11. And the results of the geotechnical investigations and the analysis are presented in Fig. 12.

\section{Countermeasures for slope stabilization}

\section{Determination of geotechnical parameters}

Geotechnical parameters for selection of reinforcement methods were determined through comprehensive and comparative analysis based on the laboratory test results, references, data of the original design, empirical formulas, other design cases, etc. Especially, the shear strength of the clay, which is the inferred slip surface, was determined through a reverse analysis by using the LEM (limit equilibrium method), assuming that the shear strength of the clay should be the value when the safety factor of the LEM reaches to $1.0[4,5]$. And the shear strength estimated by the reverse analysis was compared to the results of investigations for verification. The measured groundwater level during the investigations was applied to the analysis. Geotechnical parameters of reinforced area by grouting were determined through case studies on effects of ground reinforcement grouting. The geotechnical parameters applied for the analysis are presented in Table 1 [3]. 


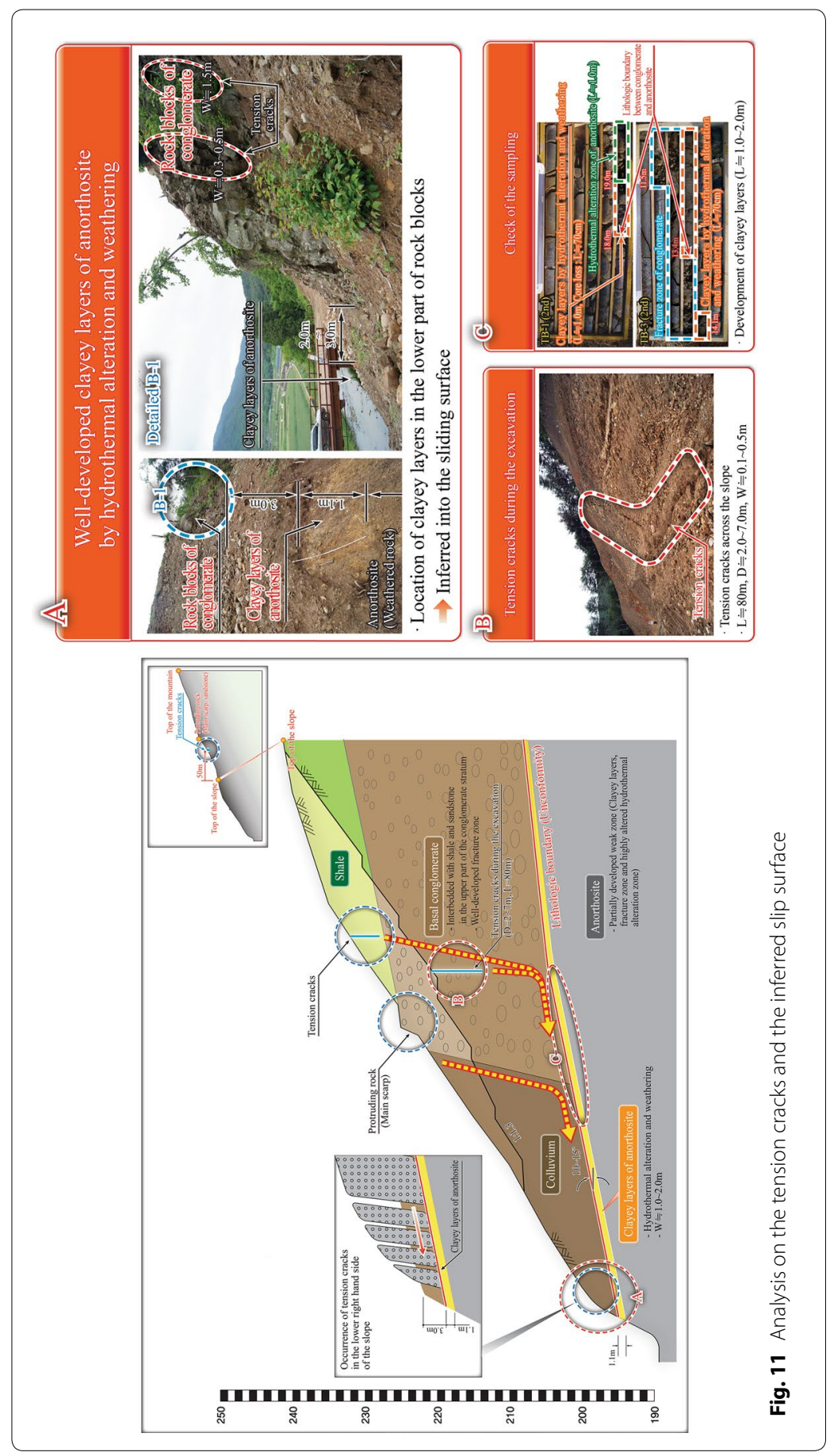




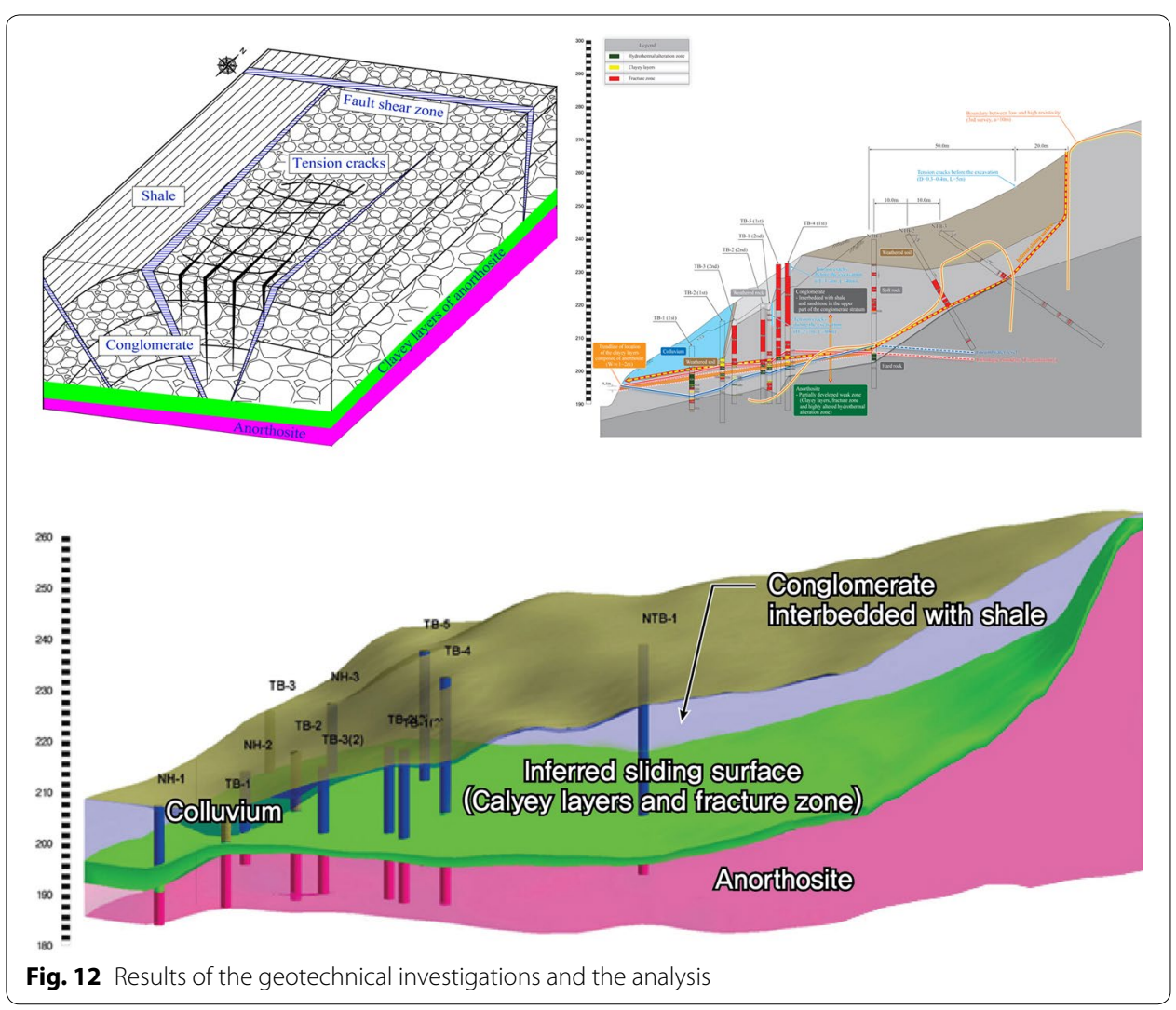

Table 1 Geotechnical parameters

\begin{tabular}{|c|c|c|c|c|c|}
\hline Category & $\begin{array}{l}\text { Unit weight, } \\
\mathrm{kN} / \mathrm{m}^{3}\end{array}$ & Cohesion, $\mathrm{MPa}$ & $\begin{array}{l}\text { Angle of internal } \\
\text { friction, deg }\end{array}$ & $\begin{array}{l}\text { Modulus of defor- } \\
\text { mation, } \mathrm{MPa}\end{array}$ & $\begin{array}{l}\text { Poisson's } \\
\text { ratio }\end{array}$ \\
\hline Colluvial soil & 18 & 0.01 & 28 & 20 & 0.35 \\
\hline Weathered soil & 19 & 0.015 & 30 & 40 & 0.33 \\
\hline Weathered rock & 20 & 0.03 & 31 & 300 & 0.30 \\
\hline $\begin{array}{l}\text { Fracture zone of soft } \\
\text { rock }\end{array}$ & 21 & 0.14 & 32 & 300 & 0.30 \\
\hline Grouting & 21 & 0.21 & 32 & 600 & 0.30 \\
\hline Soft rock & 23 & 0.3 & 34 & 2000 & 0.26 \\
\hline Hard rock & 26 & 2.0 & 37 & 10,000 & 0.23 \\
\hline $\begin{array}{l}\text { Clayey layer (inverse } \\
\text { analysis) }\end{array}$ & 18 & 0.015 & 16 & 6 & 0.35 \\
\hline
\end{tabular}

\section{Review on slope reinforcement methods}

According to the results of the geotechnical investigation, the study area shows a very complex terrain due to faults, an intrusion of igneous rocks, landslides in the past and hydrothermal alteration as well as poor quality rocks with well-developed discontinuities and a deep-seated slip surface.

The countermeasures employed in the first revised design were reduction of active forces by decrease of the slope gradient (1:1.3) with soil nailing and removal of tension cracks as shown in Fig. 13. However, additional large-scale tension cracks occurred 


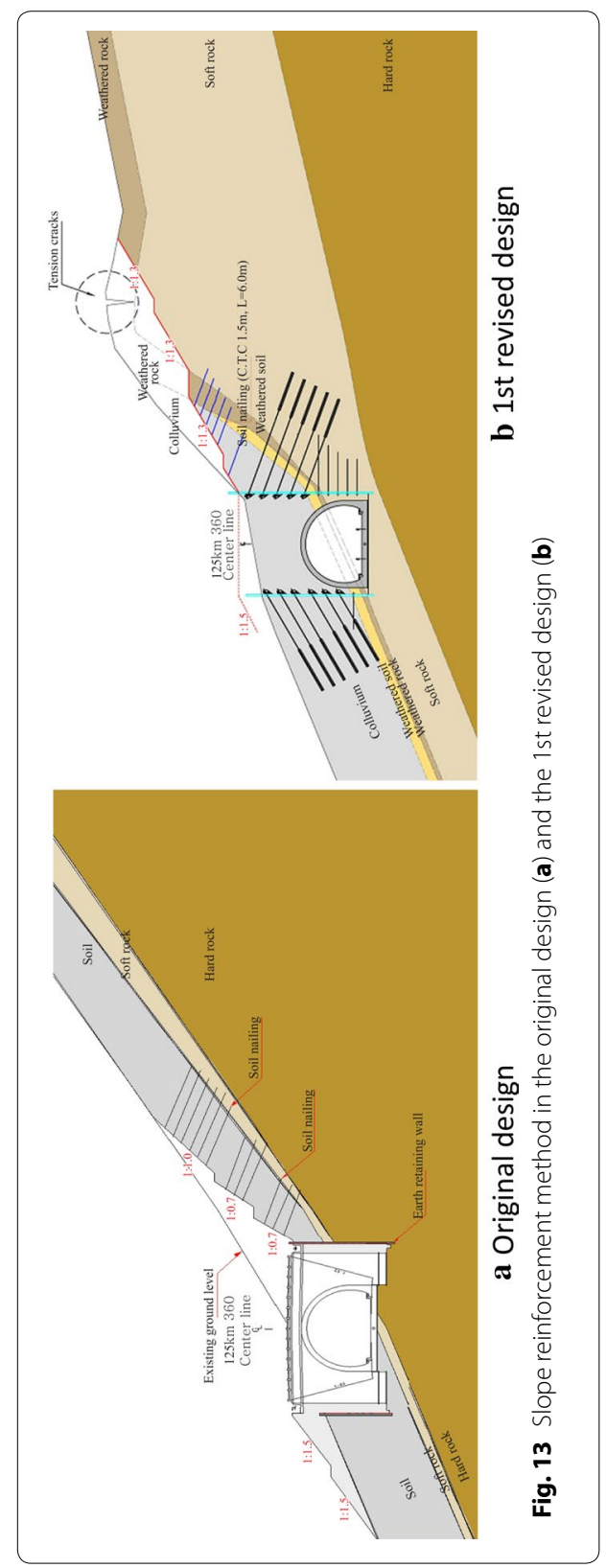


during the excavation and alternative reinforcement methods were reviewed consequently. Considering the geographical conditions, civil appeals, the deep-seated slip surface and the large-scale tension cracks in the slope, permanent anchors and stabilizing piles were designed to secure sufficient shear resistance against sliding with ground reinforcement grouting for the fracture zone near the expected failure surface. Also, soil nails are installed simultaneously to secure the stability of the upper soil of the slope as presented in Table 2 [3].

\section{Review on slope stability analysis}

The critical cross-section of the slope was selected for stability analysis of the reinforced slope, considering height of the slope, location of the slip surface, soil conditions and groundwater level based on the results of the geotechnical investigations. The LEM (limit equilibrium method) and the SRM (strength reduction method) were applied for the stability analysis of the slope under the assumption that the failure occurred along the slip surface which was inferred as the primary cause of the tension cracks. According to the result of the analysis, the stability of the reinforced slope complies with the criteria in both of dry and wet conditions. Therefore, it was concluded that the slope would be under stable condition after reinforcement. The results of the analysis are presented in Tables 3 and 4 [3].

\section{Conclusion}

Large-scale tension cracks of the slope were developed during the excavation at the tunnel portal area where landslides had occurred in the past. And geotechnical investigations were conducted to identify causes of the landslides, and to establish countermeasures to secure the long-term stability of the slope. The major findings of this case study are as follows.

Table 2 Selection of the reinforcement methods

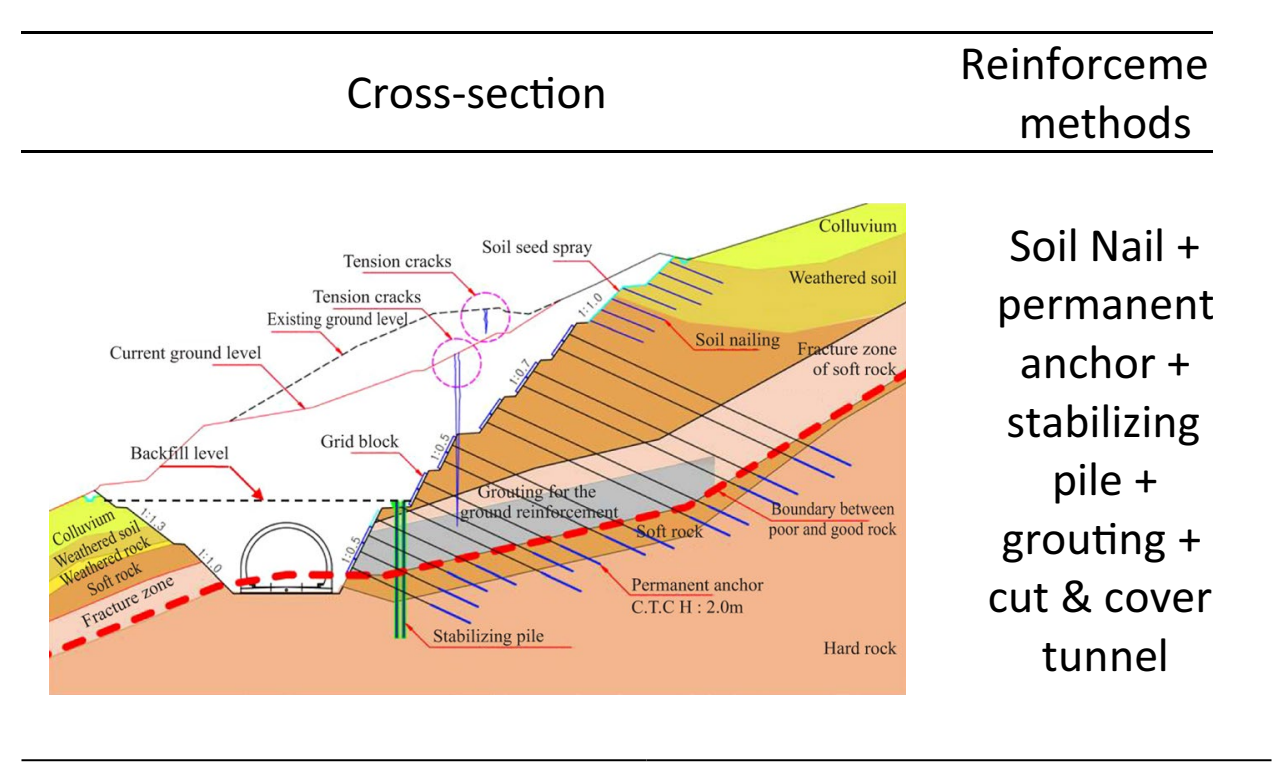


Table 3 Results of the LEM and SRM analysis

\begin{tabular}{|c|c|}
\hline $\begin{array}{c}\text { Limit equilibrium method } \\
\text { at wet condition }\end{array}$ & $\begin{array}{c}\text { Strength reduction method } \\
\text { at wet condition }\end{array}$ \\
\hline $\mathrm{FS}=1.31>1.3$ & $\mathrm{FS}=1.37>1.3$ \\
\hline
\end{tabular}

Table 4 Detailed results of the slope stability analysis

\begin{tabular}{|c|c|c|c|c|c|}
\hline \multirow[t]{2}{*}{ Category } & \multicolumn{2}{|c|}{ Limit equilibrium method (FS) } & \multicolumn{2}{|c|}{ Strength reduction method (FS) } & \multirow[t]{2}{*}{ Results } \\
\hline & Dry & Wet & Dry & Wet & \\
\hline $125 \mathrm{~km} \mathrm{370^{a }}$ & $1.54>1.5$ & $1.31>1.2$ & $1.56>1.5$ & $1.37>1.2$ & Stable \\
\hline $125 \mathrm{~km} \mathrm{390^{ \textrm {b } }}$ & $1.74>1.5$ & $1.32>1.2$ & $1.7>1.5$ & $1.4>1.2$ & Stable \\
\hline $125 \mathrm{~km} \mathrm{420^{ \textrm {b } }}$ & $1.63>1.5$ & $1.37>1.2$ & - & - & Stable \\
\hline $125 \mathrm{~km} \mathrm{450^{ \textrm {b } }}$ & $1.82>1.5$ & $1.40>1.2$ & - & - & Stable \\
\hline
\end{tabular}

a Cross-section perpendicular to the railway line

b Cross-section inclined to the railway line

1. It is estimated that the lower part of the slope in the study area had been once moved by landslides in the past. Then, it is inferred that approximately $12 \mathrm{~m}$-thick colluvium had been accumulated at the base of the steep slope by the action of gravity, and several tension cracks were extended and occurred in the slope. In spite of efforts to reduce the slope gradient to 1:1.3 including removal of the observed tension cracks (Length: $40 \mathrm{~m}$, Depth: $3-4 \mathrm{~m}$ ) for stabilization of the slope, a large-scale tension cracks (Length: $90 \mathrm{~m}$, Depth: above $7 \mathrm{~m}$ ) reoccurred during the excavation. And additional tension cracks occurred in the slope by relaxation of rock masses. It is inferred that the slope in the study area has very poor rock mass characterization as landslides continuously occurred prior to and during the excavation.

2. Detailed geotechnical investigations such as surface geological survey, electric resistivity survey, boring survey, BIPS, seismic tomography, in-situ and laboratory tests were performed three times in order to obtain information on features of strata, lithology, geological structures and engineering properties of rocks. And the results of investigations and stability analysis were effectively applied for analysis on causes of the landslides and selection of the optimum countermeasures.

3. According to the results of the investigations, the study area consists of conglomerate in the upper part which is mainly fractured and highly weathered, and anorthosite in 
the lower part, forming an unconformity between them. There are weakness zones such as the fracture zone, the clayey layers and the hydrothermal alteration zone of anorthosite, distributed along the lithologic boundary between conglomerate and anorthosite. Especially, it is inferred that the clayey layers are formed due to highly altered hydrothermal alteration and weathering. These layers have the average thickness of $1-2 \mathrm{~m}$, slanting $10-15^{\circ}$ upward. As a result of hazard assessment for the reactivated landslide of the study area, it can be inferred that the deep-seated (about $15-35 \mathrm{~m}$ ) clayey layers are the slip surface and the trigger for the movement. Primary causes of the landslides are due to increased water pressure, decrease of shear strength and frictional resistance along the clayey layers of anorthosite. The type of the landslides is a rock slide caused by parallel movement along the planes of the weakness zones.

4. Countermeasures such as permanent anchors, stabilizing piles, grouting for ground reinforcement and soil nails are applied to ensure sufficient resistance against the active force of the slope.

\section{Authors' contributions}

BSP carried out the analysis on status and causes of the landslides, developed investigation plans and countermeasures. $\mathrm{HC}$ established and managed overall plans, including preparation of the risk response strategy and decision of the final countermeasure. SPY implemented the stability and economic analysis on proposed countermeasures and gathered the final data of the study for publication. DIP collected the data with regard to status of the landslides and arranged the results of investigations for analysis on causes of the landslides. All authors read and approved the final manuscript.

\section{Competing interests}

The authors declare that they have no competing interests.

Received: 2 October 2015 Accepted: 10 February 2016

Published online: 25 February 2016

\section{References}

1. Song YS, Hong WP (2007) A case study on the analysis of cause and characteristics of a landslide at the sedimentary rock area. J Eng Geolo (Vol.17, No.1, March, 2007), p 101-113

2. Kim NJ, Kang PJ (1965) Geological map of Jingyo sheets (1:50,000). Korea Institute of geoscience and mineral resources, p 1-33

3. Korea Rail Network Authority (2012) Reinforcement design report of Jikjeon tunnel, Korea Rail Network Authority, p 9-88, p 101, p 143, p 171-176

4. You BO (2002) Assumption of shear strength on failed discontinuities due to back analysis. Fall Natl Confec Korean Geotech Soc 2012:213-227

5. Korea Expressway Corporation (1996) Road design manual—soil mechanics and foundation. Korea Expressway Corporation, p 255

\section{Submit your manuscript to a SpringerOpen ${ }^{\circ}$ journal and benefit from:}

- Convenient online submission

- Rigorous peer review

- Immediate publication on acceptance

- Open access: articles freely available online

- High visibility within the field

- Retaining the copyright to your article

Submit your next manuscript at $\boldsymbol{s p r i n g e r o p e n . c o m ~}$ 